\title{
Erratum to: Existing Challenges Associated with Offering Prenatal Genetic Diagnosis in an Arab Society in the Sultanate of Oman
}

Zandrè Bruwer • Achandira M. Udayakumar •

Khalsa Al Kharousi • Adila Al-Kindy

Published online: 6 January 2015

(C) National Society of Genetic Counselors, Inc. 2014

Erratum to: J Genet Counsel

DOI 10.1007/s10897-014-9764-x

There was an error in the name of the second author. The correct name is Achandira M Udayakumar.

The online version of the original article can be found at http://dx.doi.org/ 10.1007/s10897-014-9764-x.

Z. Bruwer $(\bowtie) \cdot \mathrm{K}$. Al Kharousi · A. Al-Kindy

Genetic and Developmental Medicine Clinic, Sultan Qaboos

University Hospital, Muscat, Sultanate of Oman

e-mail: zandrebruwer@gmail.com

A. M. Udayakumar

Genetic Department, College of Medicine and Health Sciences,

Sultan Qaboos University, Muscat, Sultanate of Oman 